НАН України; Інститут держави і права ім. В.М. Корецького. Київ, 2007. 453 с.

3. Кирилюк А.В. Правопорушення авторських прав у мережі Інтернет: поняття та види. Часопис иивілістики. 2016. № 22. C. $117-121$.

4. Закон України «Про авторське право i суміжні права» від 23.12.1993 р. № 3792-XII. Відомості Верховної Ради Украйни. 1994. № 13. Ст. 64.

5. Харитонова О.I. Порівняльно-правові дослідження піратства, контрафакції та плагіату за законодавством України та Польщі. Часопис ииивілістики. 2014. № 16. С. 222-226.

6. Шишка Р.Б. Плагіат та його прояви i небезпеки. Часопис Київського університету права. 2014. № 4. С. 170-175.

DOI https://doi.org/10.30525/978-9934-588-92-1-41

\title{
«АРХІТЕКТОНІКА» МЕХАНІЗМУ ПРАВОВОГО РЕГУЛЮВАННЯ СІМЕЙНИХ ВІДНОСИН
}

\author{
Чернега В. М. \\ кандидат юридичних наук, доиент, \\ доцент кафедри підприємницького та корпоративного права \\ Державного вищого навчального закладу «Київський національний \\ економічний університет імені Вадима Гетьмана» \\ м. Київ, Україна
}

Як зазначає Н. С. Кузнєцова, механізм правового регулювання «безпосередньо пов'язаний з ефективністю права та його інструментарію» $[1$, с. 18]. Тому неможливо не зупинитися на «архітектоніці» механізму правового регулювання сімейних відносин, яка донині в спеціальній літературі розлого не окреслена. Адже структура механізму правового регулювання переважно розглядається в працях цивільноправового спрямування. Йдеться про здобутки в цьому питанні таких українських учених: Н. С. Кузнєцової, I. С. Лукасевич-Крутник, В. В. Луця, В. В. Мазура, Н. В. Міловської, О. О. Отраднової, М. Д. Пленюк, С. О. Погрібного, I. Я. Сенюти, Р. I. Таш'яна, Н. В. Федорченко та ін. 
Зарубіжна науковиця О. О. Чефранова висновує, що до елементів механізму сімейно-правового регулювання належать: норми права, правовідносини, індивідуальні правові акти, в т.ч. акти судової практики, методологія, правоохоронна система, тлумачення норм права. Водночас учена відносить понятійний апарат до складу механізму сімейно-правового регулювання майнових відносин подружжя $[13$, с. 8$]$. Наведений підхід не $є$ безспірним. Тому в сімейноправовій думці передусім оспорюються включення до галузевого механізму правового регулювання такого елементу, як-от: правоохоронна система. Адже за своїм зміст вона пересікається 3 поняттям механізму правового регулювання сімейних відносин, проте не входить до нього [12, с. 197].

Оскільки в теорії сімейного права не визначено елементи механізму регулювання відповідного виду правових відносин, остільки корисно звернутися до надбань цивільно-правової думки в цьому питанні, де автори залежно від предмета дослідження називають їх. Так, Н. С. Кузнєцова підтримує тих учених із загальної теорії права, які вважають, що в процесі правового регулювання існує кілька стадій: a) регламентація суспільних відносин (нормотворення); б) виникнення суб'єктивних прав і суб'єктивних юридичних обов'язків; в) реалізація суб'єктивних прав і суб'єктивних юридичних обов'язків, утілення їх у конкретній, фактичній поведінці учасників суспільного відношення; г) застосування права [1, с. 16].

О. О. Отраднова висновує, що існує чотири елементи механізму цивільно-правового регулювання деліктних зобов'язань: а) норми деліктного права, правові принципи та презумпції; б) юридичні факти; в) деліктне правовідношення; г) захист порушеного права потерпілого $[6$, c. $40-41]$.

С. О. Погрібний до механізму правового регулювання договірних відносин зараховує такі складові: а) норми цивільного права; б) юридичний факт; в) цивільні права й обов'язки; г) здійснення і виконання відповідних прав та обов'язків; г) захист цивільних прав та інтересів [8, с. 147].

Н. В. Федорченко виокремлює кілька елементів механізму правового регулювання відносин 3 надання послуг: а) норми цивільного права або проновані сторонами договору про надання послуг умови; б) юридичні факти; в) права та обов'язки (правовідносини), що виникають на підставі норм цивільного права та 3 договорів про надання послуг; г) поведінку учасників правовідносин щодо надання послуг з реалізації їхніх суб'єктивних прав та обов'язків, закладених у правових норм та визначених волею замовника та 
виконавця; г) захист закладених у правових нормах та визначених волею замовника та виконавця суб'єктивних цивільних прав та законних інтересів за умови їхнього порушення [11, с. 55-56].

I. Р. Таш'ян визначає такі елементи механізму цивільно-правового регулювання транспортних відносин: а) норми права; б) юридичні факти; в) правовідносини; г) виконання обов'язків; г) акти захисту порушених прав та законних інтересів [10, с. 107].

М. Д. Пленюк до механізму правового регулювання зобов'язальних відносин зараховує: а) нормативну основу та (або) інші соціальні регулятори (норми моралі, звичаї, звичаї ділового обороту, норми канонічного права тощо); б) юридичний факт (склад); в) виникнення прав та обов'язків (правовідносин) учасників зобов'язань; г) здійснення суб'єктивних цивільних прав та виконання сторонами юридичних обов'язків; г) захист суб'єктивних цивільних прав та інтересів учасників зобов'язальних правовідносин [7, с. 200-201].

I. Я. Сенюта в структурі механізму цивільно-правового регулювання відносин 3 надання медичної допомоги виділяє кілька елементів: а) цивільно-правові норми (втілені в актах цивільного законодавства, договорі, правовому звичаї); б) юридичні факти; в) цивільноправовідносини у сфері надання медичної допомоги; г) акт (дія або бездіяльність) безпосереднього здійснення суб'єктивних прав i безпосереднього виконання цивільних обов'язків; г) цивільно-правові форми, способи та засоби захисту прав і законних інтересів учасників правовідносин у сфері надання медичної допомоги [9, с. 121].

В. В. Луць до елементів механізму правового регулювання корпоративних відносин відносить: а) нормативну основу регулювання корпоративних відносин; б) юридичні факти; в) корпоративні правовідносини; г) акти здійснення суб'єктивних корпоративних прав та виконання обов'язків; г) захист корпоративних прав та інтересів [3, с. 147-156].

На думку В. В. Мазура, до основних елементів механізму цивільноправового регулювання сервітутних відносин належать: а) цивільноправова норма та різні форми ії вираження; б) юридичний факт; в) сервітутні правовідносини; г) акти безпосереднього здійснення / виконання суб'єктивних цивільних прав та обов'язків; г) засоби захисту цивільних прав та законних інтересів суб'єктів сервітутних правовідносин [4, с. 67].

Н. В. Міловська вважає, що до елементів механізму правового регулювання договірних відносин зі страхування належать: а) норми цивільного права або погоджені сторонам договору страхування договірні умови; б) юридичні факти; в) виконання прав та обов'язків 172 
(правовідносин) учасників договірних страхових відносин; г) здійснення прав та виконання обов'язків учасників договірних страхових правовідносин, передбачених правовими нормами та визначених за домовленістю страховика та страхувальника у змісті договору; г) захист суб'єктивних цивільних прав та законних інтересів учасників договірних страхових відносин за умови їхнього порушення [5, с. 86]. I. С. Лукасевич-Крутник сжоже розглядає структуру механізму цивільно-правового регулювання, але на прикладі договірних відносин з надання транспортних послуг [2, с. 84].

3 огляду на викладене, а також із урахуванням галузевої самобутності сімейного права, до елементів механізму правового регулювання сімейних відносин слід віднести: а) норми сімейного права, сімейно-правові договори i домовленості, правові звичаї; б) юридичні факти; в) сімейні правовідносини (сімейні права i обов'язки); г) акти здійснення та захисту суб'єктивних сімейних прав i виконання обов'язків; г) правову свідомість; д) правову культуру.

\section{Література:}

1. Кузнєцова Н. С. Договір у механізмі регулювання цивільноправових відносин. Право Украӥни. 2012. № 9. С. 12-18.

2. Лукасевич-Крутник I. C. Структура механізму правового регулювання договірних відносин 3 надання транспортних послуг. Jurnalul juridic naţional: teorie şi practică. 2018. № 4 (32). C. 80-85.

3. Луць В. В. До питання про механізм правового регулювання корпоративних відносин в Україні. Спогади про Людину, Вченого, Науковия (до 60-річчя від Дня народження професора Ірини Володимирівни Жилінкової) / за заг. ред. Р. О. Стефанчука. Харків: Право, 2019. С. 147-156.

4. Мазур В. В. Механізм цивільно-правового регулювання сервітутних відносин в Україні: дис. ... канд. юрид. наук: 12.00.03. Київ, 2019. 242 с.

5. Міловська Н. В. Теоретичні засади цивільно-правового регулювання договірних відносин зі страхування: дис. ... д-ра юрид. наук: 12.00.03. Київ, 2019. 515 с.

6. Отраднова О. О. Механізм цивільно-правового регулювання деліктних зобов'язань: дис. ... д-ра юрид. наук: 12.00.03. Київ, 2014. $500 \mathrm{c}$.

7. Пленюк М. Д. Юридичні факти як підстави виникнення цивільно-правових зобов'язань (теоретичні та практичні засади): дис. ... д-ра юрид. наук: 12.00.03. Київ, 2016. 426 с. 
8. Погрібний С. О. Механізм та принципи регулювання договірних відносин у цивільному праві України: дис. ... д-ра юрид. наук: 12.00.03. Київ, 2014. 412 с.

9. Сенюта І. Я. Цивільні правовідносини у сфері надання медичної допомоги в Україні: питання теорії і практики: дис. ... д-ра юрид. наук: 12.00.03. Київ, 2018. 500 с.

10. Таш'ян P. I. Механізм цивільно-правового регулювання транспортних відносин. Університетські наукові записки. 2016. № 57. C. $101-109$.

11. Федорченко Н. В. Зобов'язання з надання послуг у цивільному праві України: дис. ... д-ра юрид. наук: 12.00.03. Київ, 2015. 443 с.

12. Чернега В. М. Механізм сімейно-правового регулювання очима цивіліста-сучасника. Актуальні наукові дослідження сучасної юридичної науки: теорія та практика: зб. матер. ІІІ-ї Наук.практ.конф. (м. Київ, 18 березня 2016 р.). Київ: ВНЗ «Університет економіки та права «КРОК», 2016. С. 196-198.

13. Чефранова Е. А. Механизм семейно-правового регулирования имущественных отношений супругов: автореф. дисс. ... д-ра юрид. наук: 12.00.03. Москва, 2007. 54 с.

DOI https://doi.org/10.30525/978-9934-588-92-1-42

\title{
ДО ПИТАННЯ СТАНОВЛЕННЯ ІНСТИТУТУ СІМЕЙНОЇ МЕДІАЦІЇ В УКРАЇНІ
}

\author{
Широковська О. 0. \\ аспірант кафедри ичивільно-правових дисииплін \\ Національної академії внутрішніх справ \\ м. Київ, Україна
}

Одним із способів урегулювання спорів в Україні вважається звернення за допомогою до юрисдикційних органів. Проте на сьогодні сучасна судова система не здатна задовольнити в повному обсязі потреби всіх осіб, які вважають, що їх права порушено.

Крім того, часто ухвалення судового рішення не означає дійсного розв'язання конфлікту, а навпаки - провокує його ескалацію [1]. Значною мірою це стосується справ, що випливають із сімейних спорів. 